\title{
Concentration Measurements of Radon 222 Indoors in Lima - Peru
}

\author{
P.Pereyra*, M.E. López, L. Vilcapoma \\ Sección Física, Pontificia Universidad Católica del Perú, Lima - Perú \\ *Corresponding author: ppereyr@pucp.edu.pe
}

Received June 30, 2015; Revised July 14, 2015; Accepted July 17, 2015

\begin{abstract}
The measurement of the levels of ${ }^{222} \mathrm{Rn}$ was accomplished during autumn to spring season in 2014 at residences distributed throughout 30 districts of Lima Metropolitan Area, including the north, centre and south areas of the city. The houses where the measurements were achieved were selected considering several variables as type of construction, age, construction materials, coatings, soil type, occupational use of rooms monitored, etc. For all the measurements of ${ }^{222} \mathrm{Rn}$ passive detectors was used (Solid State Nuclear Track Detectors SSNTDs) of cellulose nitrate (LR- 115). Procedure and data acquisition are described and results; this monitoring is the first realized in this city. The results are only indicating the presence of ${ }^{222} \mathrm{Rn}$, the detectors used do not allow to the discrimination of its descendants.
\end{abstract}

Keywords: Monitoring of ${ }^{222} \mathrm{Rn}$, nuclear tracks detectors, cellulose nitrate

Cite This Article: P.Pereyra, M.E. López, and L. Vilcapoma, “Concentration Measurements of Radon 222 Indoors in Lima - Peru.” International Journal of Physics, vol. 3, no. 4 (2015): 165-169. doi: 10.12691/ijp-3-4-5.

\section{Introduction}

${ }^{222} \mathrm{Rn}$ Gas, natural radioisotope that presents imperceptibly in our senses is the main contributor to the natural radiation received by humans. ${ }^{222} \mathrm{Rn}$ is an inert gas that emits alpha particles and has a relatively short average life (3.8 days). Radon proceeds from the decay of ${ }^{226} \mathrm{Ra}$.

Radon gas emanates in small quantities from the soil and building materials. It incorporates to the air, usually in low concentrations; decays in his daughters $\left({ }^{218} \mathrm{Po},{ }^{214} \mathrm{Po}\right)$ but it can be risky in poorly ventilated or closed areas where it is susceptible to be inhaled by living beings. In ideal conditions it should not exceed $200 \mathrm{~Bq} \cdot \mathrm{m}^{-3}[10]$.

Research works establish a close relationship between inhalation of significant concentrations of radon indoors and lung cancer. This risk increases in active smokers and even in passive smokers up to in a factor of 10. In this case, Radon is the most important factor about lung cancer incidence [11].

Although ground radon is the main source of this natural radioactivity contaminant indoors, it can sometimes come from well water or watershed. On the other hand, in certain types of houses, the building materials can also emit radon, increasing its presence, but rarely does this constitute the main cause of a high concentration. Radon can enter a house through cracks in the foundations, cracks in the walls, through the joints of the walls or internal cavities in the walls, through the spaces around the pipes, through water, etc.

The main interest of this study is the measurement of radon concentration in different types of houses in the city of Lima, considering its geographical location and give suggestion if it is suitable.

Nuclear tracks solid state detectors used in this ${ }^{222} \mathrm{Rn}$ monitoring have been used in similar investigations; methodology and fundamentals of the technique are known [4].

\section{Rationale}

Lima, the capital of Peru, is a city with near 10 million inhabitants located on the west coast of South America, in front of the Pacific Ocean at $12^{\circ}$ South Latitude and $77^{\circ} 3^{\prime}$ West Longitude, it covers an area of $3900 \mathrm{~km}^{2}$. Lima is a flat city, rounded by some hills and mountains irrelevant. Geological outcrops correspond to intrusive, extrusive and lesser sedimentary rocks amount. It is located on the valleys of Rimac, Chillon and Lurin rivers. Presents mostly alluvial gravel soils and rocky outcrops; also it presents some areas of sandy soils (seismic micro zonation of Lima).

The urban development of the city of Lima throughout its history has been increased in recent 40 years, in which its population has tripled. Mostly on the new city is over a desert terrain, but also comprises fertile areas. Due to excessive and disordered urban growth, the city extends in the so called north, south and west cones, growing on rocky, sandy terrains, slopes and hills of surrounding terrains. The province of Lima is divided into 43 districts, distributed for this study in 4 areas: North, East, Central and South.

The aim of this research is to know concentration levels of ${ }^{222} \mathrm{Rn}$ in some houses for begin to do a Radon map from Lima and to be a beginning to identify an eventual 
sanitary risk to its inhabitants related about lung cancer and others.

To conduct the measurements some houses of teachers, students and workers of Pontificia Universidad Católica del Perú (PUCP) were selected, who voluntarily collaborated to host detectors in their homes. Formerly mails were sent with concise information (scope of the project, reason of the measurements and how it would be done.) Those who answered affirmatively and were selected due to their geographic location were given additional information and guidelines for site selection of measurements in their houses and the commitment to place detectors properly. Volunteers themselves removed and placed detectors.

\section{Materials and Methods}

To conduct measurements of ${ }^{222} \mathrm{Rn}$ on the selected buildings we used passive detectors using the Nuclear Tracks technique (SSNTDs). The detectors are made of cellulose nitrate LR115 Type 2, $12 \mu \mathrm{m}$ thickness, high sensitivity, capable of recording the passage of low energy alpha particles. These detectors are not affected by electrons or other type of electromagnetic radiation (gamma radiation, X-rays, etc.). They can be stored in standard conditions for periods of time that exceed one year. Naked passive detectors were used, of square shape,
$20 \mathrm{~mm}$ by side, supported to a square bracket of $60 \mathrm{~mm}$ a side, taken from a transparency film, duly coded as shown in Figure 1.

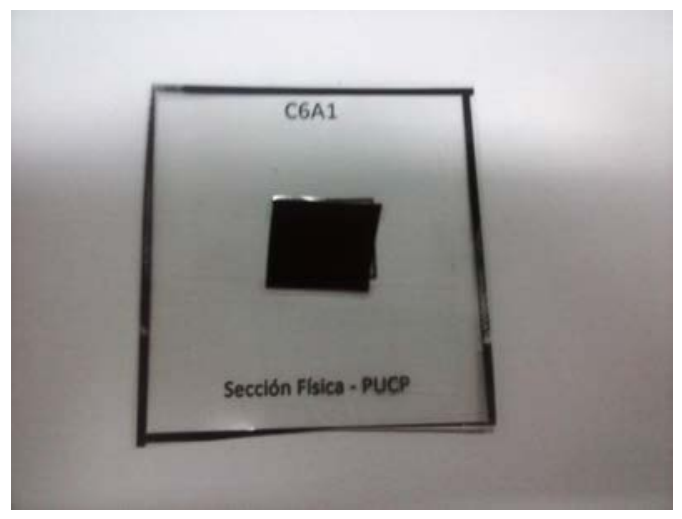

Figure 1. LR 115 detectors used in Radon 222 monitoring

\subsection{Sampling Conditions}

Three sampling areas were taken in consideration in Lima: North, Central and South. The distribution of the number of districts and number of houses monitored are shown in Table 1 and in Figure 2. The total population of this districts is 7252455 inhabitants [12] it represents about 74.5 \% from Lima population.

Table 1. Dwellings monitoring Radon in Lima by zone.

\begin{tabular}{|c|c|c|c|}
\hline Zone & Districts by zone & Districts & Number of dwellings by zone \\
\hline Central & 13 & $\begin{array}{c}\text { Lima Cercado, San Borja, Miraflores, Magdalena, Pueblo Libre, San Miguel, } \\
\text { Jesús María, Breña, Lince, La Victoria, Surco, Surquillo, San Isidro }\end{array}$ & 50 \\
\hline South Cone & 3 & San Juan de Miraflores, Villa María del Triunfo, Chorrillos & 11 \\
\hline North Cone & 5 & Independencia, Puente Piedra, San Martín de Porres, Los Olivos, Comas & 18 \\
\hline East Cone & 4 & La Molina, El Agustino, Ate-Vitarte, San Juan de Lurigancho & 18 \\
\hline
\end{tabular}

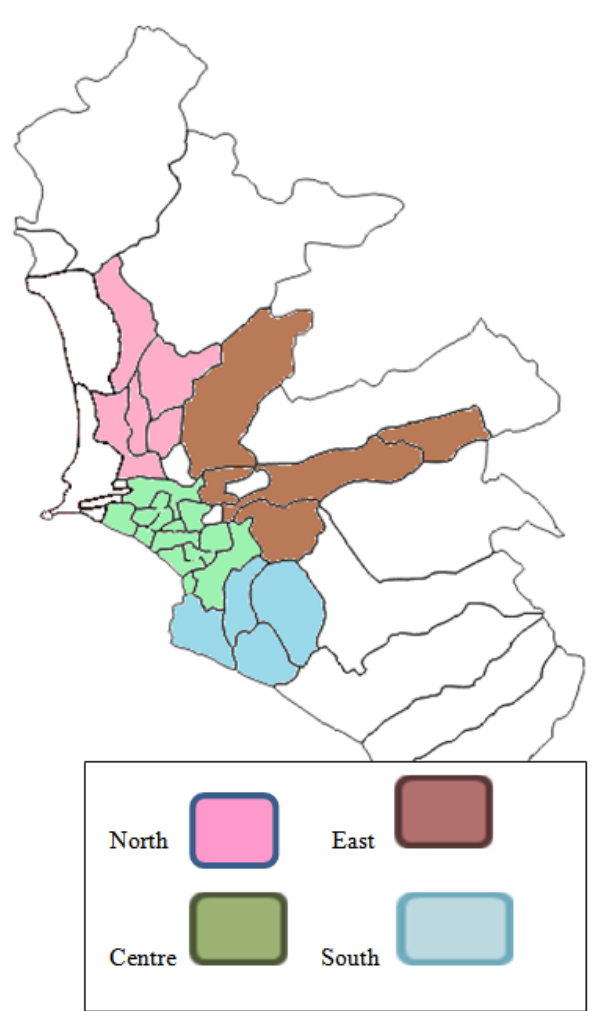

Figure 2. Geographical location of LR 115 detectors used in ${ }^{222} \mathrm{Rn}$ monitorin

The detectors were coded according to the area, and then the district selected, houses of that district A, B or C and finally the detector number (from 1 to 6). In total 396 detectors were processed.

Sampling was given in periods from 7 to 8 weeks during autumn and winter in 2014. During this period 2 detectors were placed per house, this is to say that six detectors were recorded in total for each sampling site. Indications were given to consider placing the detector at the less ventilated area of the house (bedroom, bathroom, basement, garage ....) Participants filled out a form where the characteristics of the building and lining the walls of the room and the floor were indicated, as well as the average time spent by the family in the rooms studied. Other data recorded were the age of the house, building materials and if the people who lived there were smokers or other relevant data.

\subsection{Etching and Reading Process}

Etching was made under standard conditions in a thermostated bath using $\mathrm{NaOH}$ solution. It was shown in Figure 3a. For the reading an optical microscope was used (Figure 3b), counting four fields per detector to determine the average reading. It can be used the usual procedure for these detectors [3,9]. After that, the density of traces per $\mathrm{mm}^{2}$ was determined using the calibration factor corresponding [7]. 


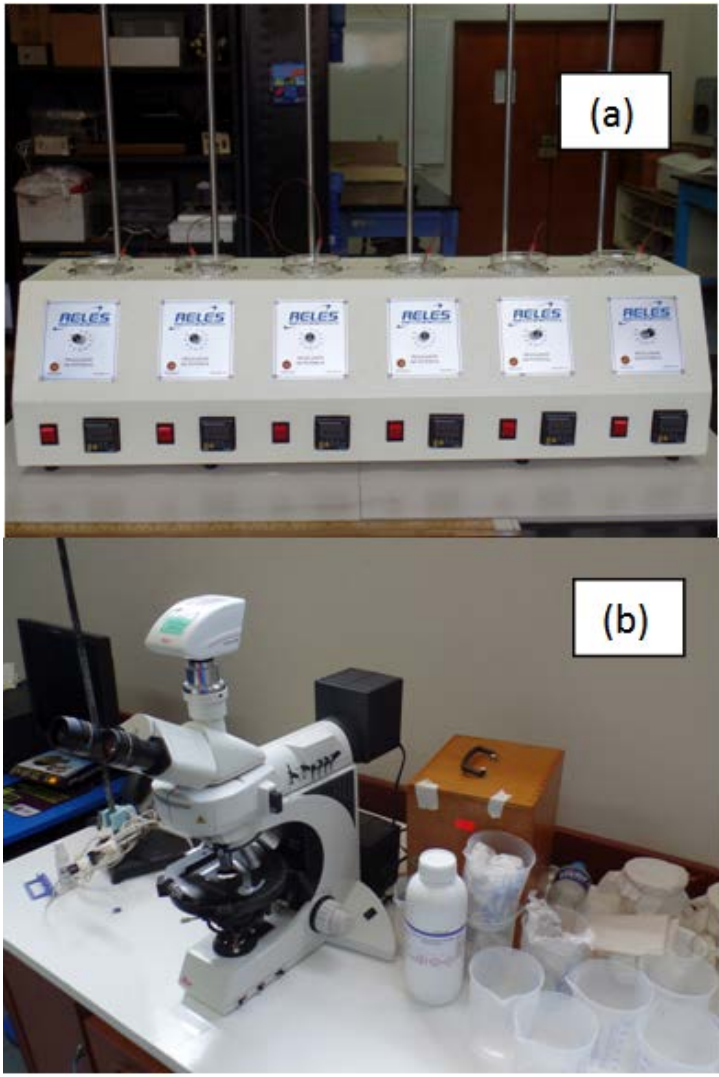

Figure 3. (a) Etching process (b) Reading process

\section{Results}

Results are shown by zones and districts in the following tables. The North zone is in Table 2; the east zone is in Table 3; the south zone is in Table 4 and the center zone is in Table 5 . The measurements above 500 $\mathrm{Bq} / \mathrm{m}^{3}$ of $\mathrm{Rn} 222$ concentration are highlighted. Some detectors were loses and the time of monitoring each of them could be inexact. Detectors were placed in basements or closed rooms, without ventilation and nonhabited.

North Zone

Monitoring was made in 5 of 8 districts of north zone, with more population and area. The population in this area is about 2129075 inhabitants [12]. It represents near 86\% population in north zone. Results are shown in Table 2.

Table 2. Monitoring results of ${ }^{222} \mathrm{Rn}$ in the Northern Area of Lima City

\begin{tabular}{|c|c|c|c|c|c|c|c|}
\hline District & 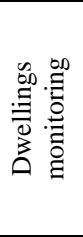 & 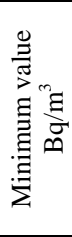 & 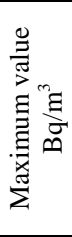 & 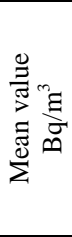 & 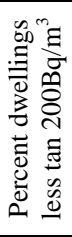 & 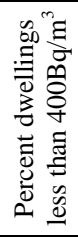 & 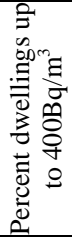 \\
\hline Puente Piedra & 1 & & & 562 & 0 & 0 & 100 \\
\hline $\begin{array}{c}\text { San Martín de } \\
\text { Porres }\end{array}$ & 8 & 20 & 632 & 205 & 62.5 & 25 & 12.5 \\
\hline Los Olivos & 4 & 48 & 162 & 108 & 100 & 0 & 0 \\
\hline Comas & 3 & 122 & 141 & 129 & 100 & 0 & 0 \\
\hline Independencia & 2 & 64 & 97 & 81 & 100 & 0 & 0 \\
\hline
\end{tabular}

East Zone

Measurements were made in 5 of the 8 districts in this zone; the districts with more population and area were selected. In the selected districts live 2101866 inhabitants [12], it represents near $81 \%$ population in the east zone. Results are shown in Table 3.

Table 3. Monitoring results of ${ }^{222} \mathrm{Rn}$ in the Eastern Area of Lima City

\begin{tabular}{|c|c|c|c|c|c|c|c|}
\hline District & 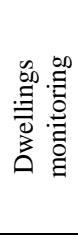 & 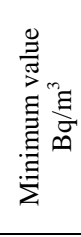 & 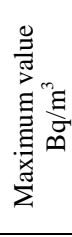 & 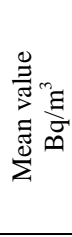 & 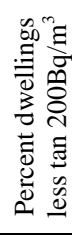 & 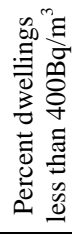 & 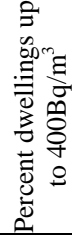 \\
\hline Ate & 2 & 9.48 & 257 & 133 & 50 & 50 & 0 \\
\hline Chacla cayo & 2 & 214 & 251 & 232 & 0 & 100 & 0 \\
\hline El agustino & 1 & 1 & & 272 & 0 & 100 & 0 \\
\hline $\begin{array}{l}\text { San juan de } \\
\text { Lurigancho }\end{array}$ & 10 & 81 & 432 & 173 & 70 & 0 & 30 \\
\hline La Molina & 3 & 22 & 180 & 96 & 100 & 0 & 0 \\
\hline
\end{tabular}

South Zone

Measurements were made in 5 of the 7 districts in this zone, with most demographic density. In this selected districts live 1618049 inhabitants [12], it represents near $71 \%$ population in the east zone. Results are shown in Table 4.

Table 4. Monitoring results of ${ }^{222} \mathrm{Rn}$ in the Southern Area of Lima City

\begin{tabular}{|c|c|c|c|c|c|c|c|}
\hline District & 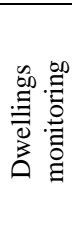 & 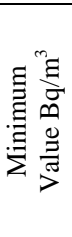 & 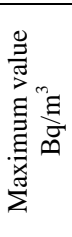 & 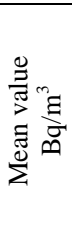 & 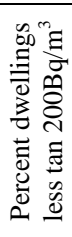 & 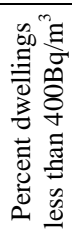 & 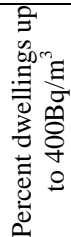 \\
\hline Chorri llos & 2 & 17 & 75 & 46 & 100 & 0 & 0 \\
\hline $\begin{array}{c}\text { San Juan de Mira } \\
\text { flores } \\
\end{array}$ & 5 & 23 & 387 & 219 & 20 & 80 & 0 \\
\hline Villa el Salvador & 1 & & & 173 & 100 & 0 & 0 \\
\hline $\begin{array}{l}\text { Villa María del } \\
\text { triunfo }\end{array}$ & 3 & 18 & 319 & 214 & 33 & 66 & 0 \\
\hline
\end{tabular}

\section{Centre Zone}

Measurements were made in 12 of the 16 districts in this zone; the districts with more population and area were selected. In the selected districts live 1543180 inhabitants [12], it represents near $83 \%$ population in the east zone.

Results are shown in Table 5.

Table 5. Monitoring results of ${ }^{222} \mathrm{Rn}$ in the Central Area of Lima City

\begin{tabular}{|c|c|c|c|c|c|c|c|}
\hline District & 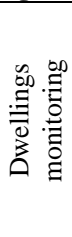 & 目兽总 & 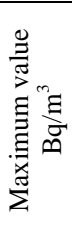 & 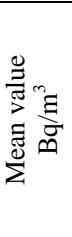 & 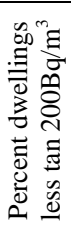 & 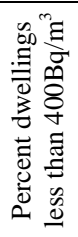 & 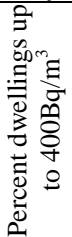 \\
\hline Breña & 2 & 156 & 348 & 252 & 50 & 50 & \\
\hline Jesús María & 3 & 70 & 136 & 112 & 100 & & \\
\hline Lince & 2 & 129 & 269 & 199 & 50 & 50 & \\
\hline $\begin{array}{c}\text { Magdalena del } \\
\text { Mar }\end{array}$ & 4 & 90 & 305 & 181 & 40 & 60 & \\
\hline Miraflo res & 5 & 57 & 942 & 312 & 40 & 40 & 20 \\
\hline Pueblo Libre & 6 & 118 & 268 & 185 & 67 & 33 & \\
\hline San Borja & 4 & 0 & 658 & 221 & 75 & 0 & 25 \\
\hline San Miguel & 11 & 20 & 480 & 178 & 64 & 27 & 9 \\
\hline La Victoria & 2 & 109 & 129 & 119 & 100 & 0 & 0 \\
\hline Lima Cercado & 7 & 61 & 604 & 246 & 42 & 29 & 29 \\
\hline Surco & 2 & 109 & 285 & 197 & 50 & 50 & 0 \\
\hline Surqui llo & 1 & & & 584 & 0 & 0 & 100 \\
\hline
\end{tabular}


Summarizing results by zone are shown as follow

\begin{tabular}{|l|c|}
\hline & Mean ( Bq/m $\left.{ }^{3}\right)$ \\
\hline North & 177 \\
\hline East & 168 \\
\hline South & 182 \\
\hline Central & 205 \\
\hline
\end{tabular}

Districts were shown now in relation with the concentration level measures obtained. It is noted that detectors with higher concentration was located in central zone. In this zone the dwellings are older (overall in Lima Cercado). San Juan de Miraflores and Villa el Salvador are the highest means at south zone; they are located in granular and sedimentary soils. Most of them who present low levels of Radon are located in rocky soils. In the case of Puente Piedra and Surquillo only one dwelling has been monitoring, so the result are not representative.

A tentative radon map is shown in Figure 4. Level concentration mean of ${ }^{222} \mathrm{Rn}$ by zone are shown in Figure 5 for each district. Districts with only one dwelling were not considered [8].

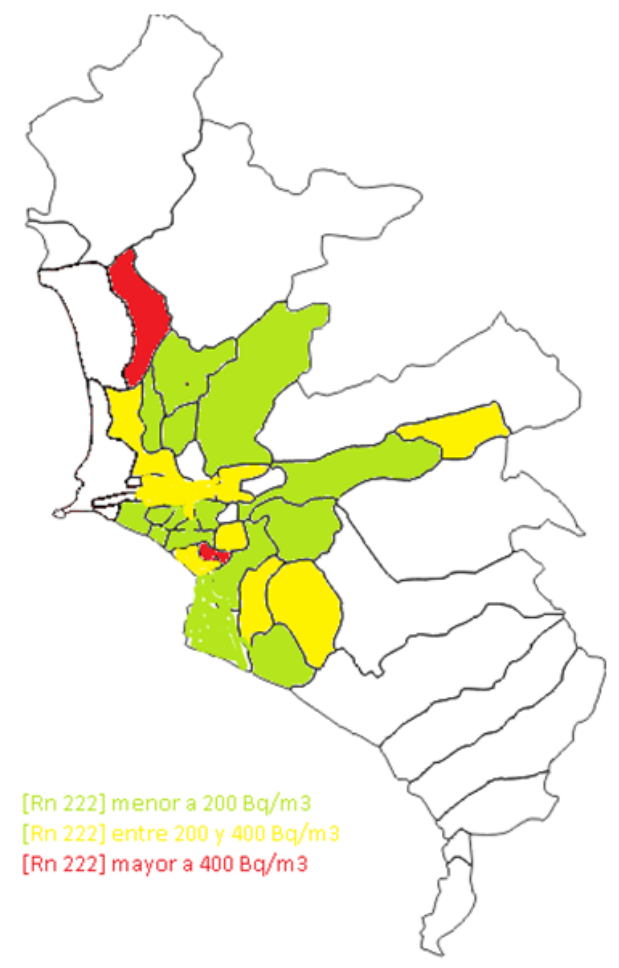

Figure 4. Districts of Lima and concentration of ${ }^{222} \mathrm{Rn}$ registered

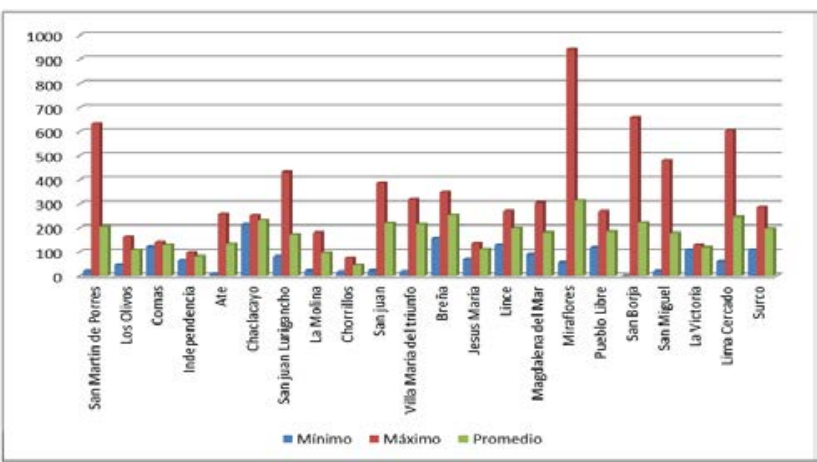

Figure 5. Concentration levels of ${ }^{222} \mathrm{Rn}$ in $\mathrm{Bq} / \mathrm{m}^{3}$ - Average values by district in Lima

\section{Conclusions}

The first approach in environmental monitoring of Radon 222 in the city of Lima has been accomplished. Reports of similar investigations employing SSNTDs in other cities have similar results $[1,5,6]$. In general most detectors recorded values corresponding to concentrations below $200 \mathrm{~Bq} / \mathrm{m} 3$; when registering high values, it may indicate a correlation between the age of the house and the level of ${ }^{222} \mathrm{Rn}$; these levels are increased in basements considerably, and are just 3 of the 4 cases with a higher concentration of ${ }^{222} \mathrm{Rn}$ measured. It can also be understood that in the case of basements, water pipes increase radon levels with poor ventilation, a key factor in the diffusion of radon. Variables such as building materials and floor and wall coverings require further analysis and data number. In general the methodology is consistent and concentration gives similar results to other methods in similar geographic locations.

\section{Acknowledgment}

The authors thank the members of the Pontificia Universidad Católica del Perú community: Heads, teachers in Physics and Industrial Engineering, administrative staff, undergraduate students in physics and General Studies (Science and Letter) who cooperated willingly and hosted the detectors in their homes.

\section{References}

[1] Canoba, A., López, F.O., Arnaud, M.I., Oliveira, A.A., Neman, R.S., Hadler, J.C., Iune, P.J., Paulo, S.R., Osorio, A.M., Aparecido, R., Rodríguez, C., Moreno, V., Vásquez, R., Espinosa, G., Golzarri, J.I., Martínez, T., Navarrete, M., Cabrera, I., Segovia, N., Peña, P., Taméz, E., Pereyra, P., López-Herrera, M.E., Sajo-Bohus, L., "Indoor radon measurements in six Latin American countries", Geofísica Internacional (2002), Vol. 41, Num. 4, pp. 453-457 (2002).

[2] Espinosa, G., Trazas Nucleares en Sólidos, UNAM, México, ISBN: 968-36- 4219-5 (2002).

[3] Fleischer, R.L., Price, P.B., Walker, R.M., Nuclear Tracks in Solids: Principles and Applications, University of California Press, Berkeley (1975).

[4] Fleischer, R.L., Price, P.B., Walker, R.M., "Solid State track detector: application to nuclear science and geophysics", Annu. Rev. Nucl. Sci., 15, pp. 1-28 (1965).

[5] Gupta, M., "Monitoring of indoor radon and its progeny in dwellings of Delhi using SSNTDs", Advances in Applied Science Research 2, (5): 421-426 (2011).

[6] Liendo, J., Sajó-Bohus, L., Pálfavi, J., Greaves, E.D., Gomez, N., "Radon monitoring for health studies in the Caracas subway using SSNTDS”, Radiation Measurements, Vol. 28, Issues 1-6, 1997, Pag. 729-732 (1997).

[7] Pereyra, P., Aplicación de la técnica de huellas nucleares en dosimetría de partículas alfa, Tesis de bachiller de la Pontificia Universidad Católica del Perú (1991).

[8] Santos, T., Rocha, Z., Barreto, A.A., de Souza, A., Miguel, R., de Oliveira, A., Indoor radon distribution in metropolitan region of Belo horizonte, Brasil Proceedings 2009, International Nuclear Atlantic Conference - INAC 2009 ISBN: 978-85-99141-0 (2009).

[9] Urban, M., Piesch, E., "Low level environmental radon dosimetry with a passive track etch detector device”, Radiat. Protect. Dosimetry, 1, pp. 97-109 (1981).

[10] ICRP, Lung Cancer Risk from Exposures to Radon Daughters, ICRP Publication 50 (1987).

[11] ICRP, Lung Cancer Risk from Radon and Progeny and Statement on Radon, ICRP Publication 115, (2010). 
[12] "Instituto nacional de estadística e informática," http://www.inei.gob.pe/media/MenuRecursivo/publicaciones_digit ales/Est/Lib1157/libro.pdf (2014).

[13] "A citizens guide to Radon Homepage United State Environmental Protection Agency” http://www.epa.gov (2013).
[14] Eappern, K.P., Mayya, Y.S, "Calibration factors for LR 115 (type II) based radon thoron discriminating dosimeter", Radiation Measurements, 38, pp 5-17 (2014). 